\title{
Investigation on Optical Properties of CuS and Zn Doped CuS Thin Films by Chemical Bath Deposition Method
}

\author{
A. Sahana Fathima ${ }^{1}$, N. Sivaguru ${ }^{2}$, Dr. V. Senthil Kumar ${ }^{3}$ \\ Department of Physics, Karpagam University, Coimbatore, India.
}

\begin{abstract}
For decades copper sulfide has been considered as the most superior optical and semiconductor material. An attempt has been made to prepare bare and Zn doped CuS thinfilms by simple chemical bath deposition method. The prepared samples were characterized by XRD, UV and PL to identify and study its structural and optical properties. Results of XRD analysis confirmed the formation of CuS of Covellite phase. Optical properties were studied and the material exhibits a band gap of $2.41 \mathrm{eV}$ and $2.39 \mathrm{eV}$ for pure and $\mathrm{Zn}$ doped samples respectively.
\end{abstract}

Keywords: Copper Sulphide, Co-vellite, band gap.

\section{Introduction}

$\mathrm{Cu}_{\mathrm{x}} \mathrm{S}$ is an II-IV group compound which is one of the most interesting materials, for it has semiconducting properties exist in several crystallographic and stoichiometric forms. Owing to its electrical conductivity and optical bandgap, it is mainly used in solar cell applications[1]. Based on the various parameters, Copper Sulfide exhibits different crystallographic orientation. Copper Sulfide is found to be existing in two forms: "Copper rich phase" and "Copper poor phase". They are chalcocite $\left(\mathrm{Cu}_{2} \mathrm{~S}\right)$, djurlite $\left(\mathrm{Cu}_{1.96} \mathrm{~S}\right)$, digenite $\left(\mathrm{Cu}_{1.8} \mathrm{~S}\right)$, anilite $\left(\mathrm{Cu}_{1.75} \mathrm{~S}\right)$ and co-vellite $(\mathrm{CuS})$. Out of all these stoichiometric forms, covellite comes under copper poor phase [2].

There are several techniques used to prepare copper sulfide thinfilms [3]. They are spray pyrolysis, solid state reaction, vacuum evaporation, reactive magnetron sputtering, atomic layer deposition (ALD), activated reactive evaporation, chemical vapour deposition (CVD), chemical bath deposition (CBD) etc. Among these methods, chemical bath deposition is selected for the present work, for the method is simple, economic, non-pulling, and capable to attain large area coating [16]. CBD method is convenient for preparing homogenous and smoother thin films with required thickness with different dopents. In general, copper sulfide pentahydrate and sodium thiosulfate are selected as raw material to prepare copper sulfide thin films. Zinc chloride is used as dopent and EDTA is used as a clamping agent. Even though Zinc is used as the dopent, there is no report available in this regard. Thus, this study aims at making a report on chemical bath deposited copper sulfide thin films with zinc doped films, based on the investigation done using different techniques.

\subsection{Preparation of Copper sulfide (CuS) thin films:}

\section{Experimental}

Analytical-grade compounds are used to prepare the samples. Copper sulfide pentahydrate and sodium thiosulfate are taken as raw materials to prepare copper sulfide thin films. As a typical procedure 1:1 ratio of the raw materials are dissolved in $25 \mathrm{ml}$ of deionised water, and then $25 \mathrm{ml}$ EDTA solution is added to the mixture as a clamping agent. Then, Ammonium hydroxide was added to maintain the $\mathrm{pH}$ of solution at 3 . Finally the resulting solution was stirred for several minutes to maintain the $\mathrm{pH}$ value. After stirring for several minutes, pretreated substrates were immersed into the prepared bath at $50^{\circ} \mathrm{C}$ temperature. While copper sulfide thin films are still prepared, the zinc is added as the dopent material. When the final material is obtained the substrates are removed and rinsed with deionized water and dried in air at room temperature for further characterization.

\subsection{Characterization}

The samples were characterized using X-Ray diffractometry (XRD) and optical analysis (UV-Vis spectrometry). XRD was performed using XPERT-PRO model.

\subsection{Structural Analysis}

\section{Result And Discussion}

The XRD of the deposited CuS thin film and zinc doped copper sulfide thin films were grown on glass substrates at $\mathrm{pH} 3$. The broad hump in the films, $2 \theta$ ranges $15-35^{\circ}$ due to the glass substrates. The XRD patterns clearly indicates that as deposited $\mathrm{CuS}$ thin films and zinc doped $\mathrm{CuS}$ thin film reveals crystalline nature with the preferred orientation along (1 24 ) and it is exactly matches with JCPDS card no 41-0959. 
The deposited and zinc doped thin films contains single phase tetragonal primitive co-vellite phase of $\mathrm{CuS}$. The best crystallinity is obtained for the zinc doped $\mathrm{CuS}$ thin films deposited at $\mathrm{pH}=3$. Their crystalline

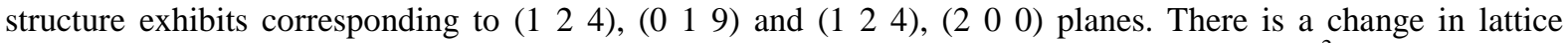
parameter $\mathrm{CuS}$ value when Zinc is doped with $\mathrm{CuS}$. This is because of the ionic radius of $\mathrm{Zn}^{2+}[0.74]$ is larger than that of $\mathrm{Cu}^{2+}$ [0.73]. From the XRD data there is an increase in grain size for $\mathrm{Zn}$ doped $\mathrm{CuS}$ thin films. This is mainly due to the incorporation of $\mathrm{Zn}$ atoms in the films.

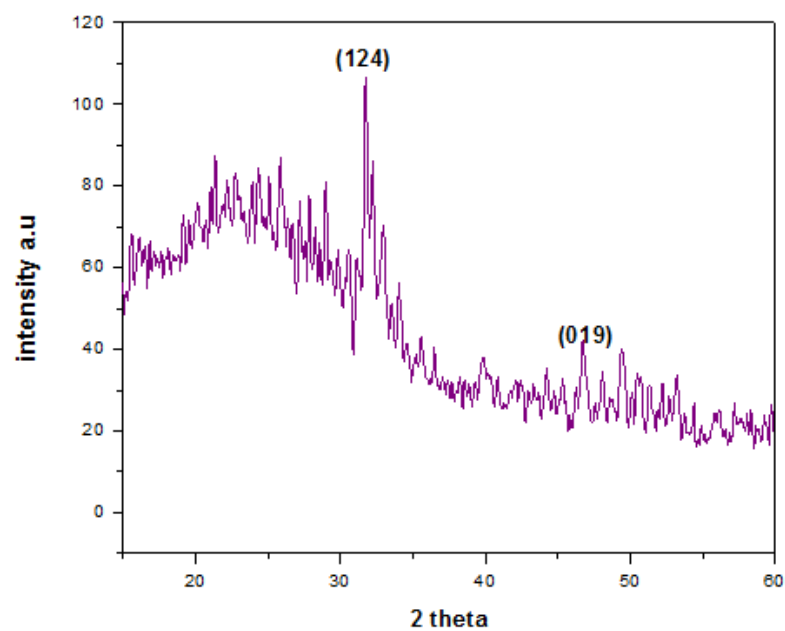

Fig.1 XRD spectrum of CuS thin film

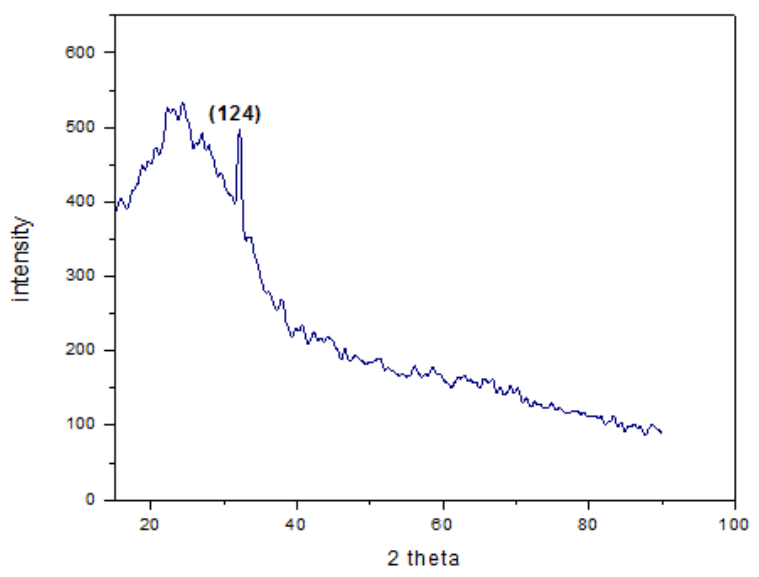

Fig. 2 XRD Spectrum of zinc doped CuS thin films

The XRD shows that intensity of peak increases with the incorporation of $\mathrm{Zn}$ atoms to the material. The lattice parameters are calculated for the deposited and zinc doped CuS thin film samples are found to be in excellent agreement with the standard value and the lattice parameter are calculated for the zinc doped CuS thin film samples are found to be in excellent agreement with increase the value. The grain size is increased in zinc doped copper sulfide thin film. The micro structural parameters such as grain size, micro strain, and dislocation density are calculated from XRD data. From the deposited result, it is clear that changing parameters of dislocation and strain are directly proportional to each other, as in the zinc doped $\mathrm{CuS}$.

Table 1: Structural parameters of chemically deposited CuS and Zinc doped CuS thin films

\begin{tabular}{|l|l|l|l|l|l|l|}
\hline Sample & $\begin{array}{l}\text { Grain } \\
\text { size }(\mathrm{nm})\end{array}$ & $\begin{array}{l}\text { Lattice parameter } \\
(\AA)\end{array}$ & $\begin{array}{l}\text { Cell volume } \\
(\AA)^{3}\end{array}$ & $\begin{array}{l}\text { Dislocation } \\
\text { density } \\
\left(10^{15} \text { Lines } / \mathrm{m}^{2}\right)\end{array}$ & $\begin{array}{l}\text { Strain } \\
\left(10^{-3} \mathrm{M}\right)\end{array}$ \\
\cline { 3 - 5 } & $\mathrm{a}$ & $\mathrm{c}$ & & 1.2203 & 1.2425 \\
\hline $\mathrm{CuS}$ & 286.2622 & 7.893 & 18.19 & 1132.36 & 1.36 & 0.9839 \\
\hline $\mathrm{CuS}+\mathrm{Zn}$ & 360.3442 & 7.290 & 21.41 & 1138.16 & 7.7013 & \\
\hline
\end{tabular}

\subsection{Optical Analysis}

\subsubsection{UV-Spectroscopy}

The optical properties of $\mathrm{CuS}$ and zinc doped $\mathrm{CuS}$ thin films deposited on glass substrates are determined from the absorbance (A) and transmittance (T) measurements in the ranges between 200-1200 nm. 
All the film exhibits the absorption on the shorter wavelength. High absorbance value shows on the $\mathrm{Zn}: \mathrm{CuS}$. The curve shows a decay of absorbance with longer wavelength and also progressive increase in absorbance. The transmittance spectra show that as-deposited films are highly transmitted than the $\mathrm{Zn}: \mathrm{CuS}$ thin film at visible region. The higher transmittance indicates the surface and relatively good homogeneity of the thinner film.

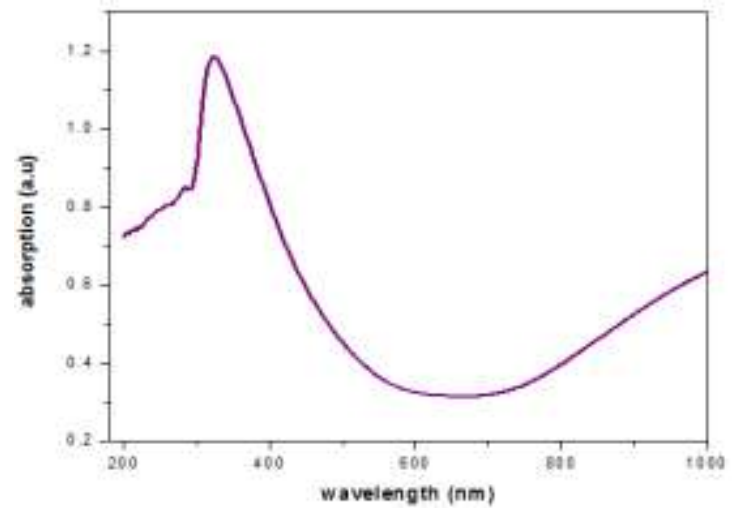

Fig. 3 Wavelength vs Absorbance of CuS thin film.

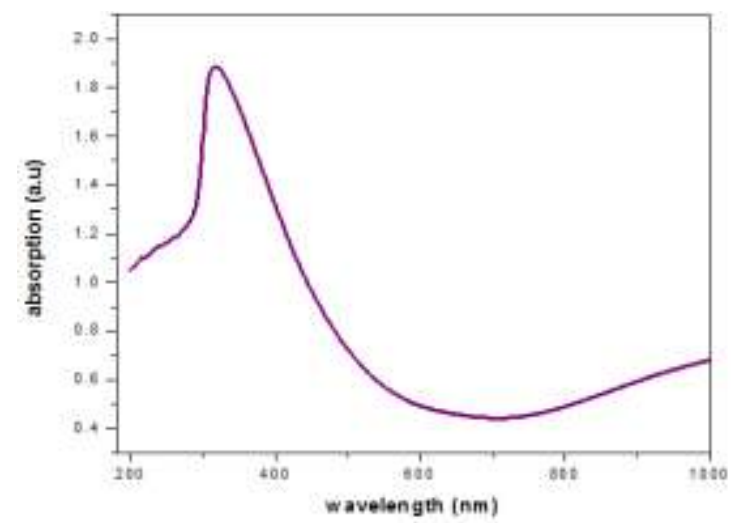

Fig. 4 Wavelength vs Absorbance of Zinc doped CuS thin film

The bandgap have been determined from the intercept of straight line portion of ( $\alpha \mathrm{h} \vartheta)^{2}$ versus (h $\vartheta$ ) and for different value of $\mathrm{CuS}$ and Zinc doped $\mathrm{CuS}$ thin films. Extrapolating the straight line portion of the plot of $(\alpha h \vartheta)^{2}$ against $(\mathrm{h} \theta)$ to energy axis for zero absorption coefficient $(\alpha=0)$ gives optical bandgap energy.

It is found that the bandgap of the $\mathrm{CuS}$ and Zinc doped $\mathrm{CuS}$ thin film samples are 1.49 and $1.43 \mathrm{eV}$ respectively. The as deposited thin film shows increase in the bandgap value and Zinc doped CuS films shows decrease in bandgap value. The bandgap arises due to following reason (i) large density of dislocation (ii) height of the crystalline films. The decrease in bandgap is caused due to the increase in the height of the crystalline films. The energy bandgap shows that these films can be used as potential absorbers in solid state solar cells.

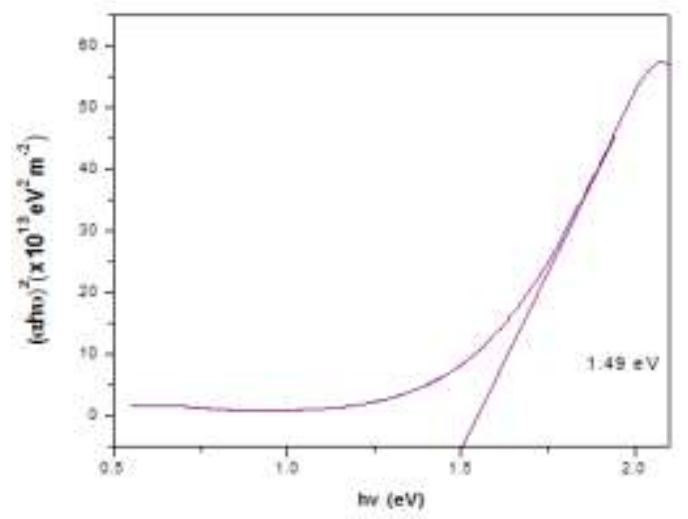

Fig. 5 plot of ( $\alpha h 9)^{2}$ vs (hv) for CuS thin films 


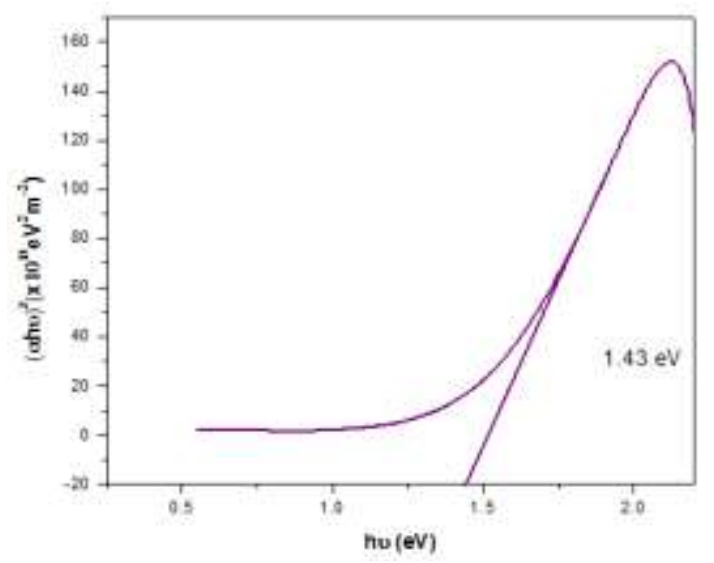

Fig. 6 Plot of ( $\propto$ h 9$)^{2}$ Vs (hv) for Zinc doped CuS thin film

\section{Conclusion}

$\mathrm{CuS}$ and Zinc doped Copper Sulfide thin films were deposited on glass substrates using chemical bath deposition technique at molar concentration of $0.5 \mathrm{M}$. This method is found to be simple and cost effective as the UV analysis shows high absorption value for $\mathrm{Zn}$ doped $\mathrm{CuS}$ thin films. $\mathrm{Zn}$ doped with $\mathrm{CuS}$ films shows reduction in band gap compared to the deposited films. As a result, from this analysis it is obvious that this material can be used as an effective material for solar cell application.

\section{References}

[1]. M.Ramya and S.Ganesan., Int. J. Pure and Appl. Phy. 6(3) 2010, 243-249.

[2]. E. Guneri, A.Kariper., J.Alloys compds.,516, (2012) 20-26.

[3]. J.J. Loferski, J. Shewchun, S.D. Mittleman, A.E. DeMeo, R. Beauliew and G. Chapman, Sol. Energy Mater 157 (1979).

[4]. M. Savelli, J. Bougnot, H. Luquet, M. Perotin, O. Maris and C, Gril, Solar cells, 5 (1) (1982). 213.

[5]. Nourhene Kamoun Allouche, Tarak Ben Nasr, Cathy Guasch, Najoua Kamoun Turki, C.R.Chime 13 (2010) $1364-1369$.

[6]. E.L.Jorten, J. Electrochem. Soc., 108 (1981) 478.

[7]. S.Middleman, A.K.Hochberg, Process Eng. Analysis in Semicond. Device Fabrication, McGraw-Hill Book Company (1993)

[8]. Ludmila Eukertova, Phys. of Thin films, New York (1986) 17.

[9]. Bharana godbole, Nitu Badera, S.B.Shaivastar, V.Ganesan, J1. of Instrum. Soc. Of India, 39 (2009) 42.

[10]. D.E.Bode, Proceedings on National Electron Conf., 19 (1963) 630.

[11]. J.D.Desai, C.D.Lokhande, J. of Non-crystalline solids, 181 (1995) 70.

[12]. R.S.Mane, B.R.Sankapal, C.D.Lokhande, Thin Solid Films, 353 (1999) 29.

[13]. J.E.Reynolds, J. Chem. Soc., 45 (1884) 162.

[14]. K.L.Chopra, Suhit Ranjan Das, Thin Film Sol. Cells, Plenum Press, New York (1983).

[15]. S.Gorer, G.Hodes, J. Phys. Chem., 98 (1994) 5338.

[16]. B.K.Gupta, O.P.Agnihotri, Phli.Mag., 37 (1978) 631.

[17]. R.D.Tarey, R.S.Rastogi, K.L.Chopra, The Rigaku J., 4 (1987) 11.

[18]. B.D.Culity, Elements of X-Ray Diffraction, Additional-Wasley Reading, USA (1978) 284.

[19]. B.K.Rai, H.D.Bist, R.S.Katiyar, M.T.S.Nair and P.K.Nair, J. Appl. Phys., 82 (1997) 1310

[20]. P.K.Kalita, B.K.Sharma, H.L.Das, Bull. Mater., Sci., 23 (2000) 313.

[21]. G.B.Williamson, R.C.Smallman, Phil. Mag., 1 (1956) 34.

[22]. B.D.Culity, Elements of X-ray diffraction, Addision Company Reading, Massachusetts USA, 2 (1978).

[23]. Sunglac Cho, Yunki Kin, Antonio Divenere, George K.Wong, John B.Ketterson, Jerry R.Meyar, Appl. Phys. Lett., 75 (1999) 1401 .

[24]. B.E.Warren, X-ray diffraction, Addision Wesley Publishing Co, London (1969).

[25]. K.L.Chopra, Thin Film Phenomena, McGraw-Hill Book Company, New York (1967) 721.

[26]. D.E.Gray, American Institute of Phys. Hand Book, McGraw-Hill Publications, New York (1957).

[27]. W.Dremtoder, Laser Spectroscopy-Basic Concepts and Instrum., Springer International Ed, Hawaii, USA (2004).

[28]. G.D.Brownline, Z. Zhu, G.Horsburgh, T.Steele, P.J. Thompson, J.M. Wallace, K.A. Prior, and B.C. Cavenett., J. Crystal growth 159 (1996) 321-324. 